\title{
SMALL RETAILER CREDIT SOURCES
}

\author{
Theodore H. SMITH*
}

Lest the reader be misled by the broad title, let it be said that this presentation will limit itself to sources of working capital credit available to small retailers, other than commercial bank sources. Before discussing the various forms of credit, it seems advisable to determine the extent to which retail institutions fall into the class of small business. In recent years, the extensive advertising by chain store organizations, large department stores and mail order houses may have created the impression that these organizations originate the majority of retail sales. An analysis of the most recent Retail Census, that of 1939, discloses that at the time the Census was taken, there were $1,770,355$ retail stores. Of these, 91 percent, or $1,613,673$, were unincorporated businesses actively managed by the proprietor $;^{1} 86$ percent, or $\mathrm{x}, 52 \mathrm{I}, \mathrm{I} 45$, were independently owned single-unit stores with an average sales volume of $\$ 18,024$, and handled 65.2 percent of all retail sales. ${ }^{2}$ After a review of these figures, and making allowances for independently owned department stores and a few other large retail establishments, it seems certain that by the use of any reasonable yardstick for dividing retail businesses into large and small concerns, nine out of ten should be regarded as small.

The working capital needs of a retailer center about his inventory requirements, his inventory turnover, his accounts receivable and the rapidity with which they can be liquidated, plus a certain amount of cash for his day-to-day expenditures.

In an analysis of $27 x$ retail trade companies, made in 1943 and including retail establishments of all sizes and kinds, the working capital represented 68 percent of all assets, and inventories and receivables in combination represented 44 percent of the total assets, indicating the important role working capital plays in retailing. ${ }^{3}$ Standards of requirements for working capital have been developed in various lines of retail trade, particularly for department stores, specialty stores and variety chains, but little has been prepared for the small retailer which can be regarded as authori-

* A.B., I921, M.B.A., 1926, Northwestern University; Ph.D., I940, Ohio State University. Special Assistant, Division of Security Loans, Board of Governors of the Federal Reserve System, Washington, D. C. Professor of Marketing, University of Oklahoma. Lecturer, American University. Author of MARRETING OF UsED AUTOMOBILES (I94r) and private research studies for newspapers and markcting organizations.

${ }^{1}$ U. S. Bur. of Census, Sixteenth Census of the United States (1940), Census of Business, Vol. I, Retail Trade: 1939, part X, p. 63, Table 3 A.

2 Id. at p. 69 , Table $3 \mathrm{~F}$.

${ }^{3}$ Robert Morris Associates and Federal Reserve System, Survey of Business Finance (1943) 14. (Published by Robert Morris Associates.) 
tative. Since commercial bank credit is not to be included in this paper, the discussion will be limited to mercantile credit and credit obtained through the pledging of accounts receivable.

\section{Mercantile Credit}

Mercantile credit, sometimes referred to as commodity or trade credit, is extended by one businessman to another, and generally implies the receipt of goods by one party, to be paid for at a later date. While such credit is generally unsecured, it is at times based upon a bill of lading, a warehouse receipt, a promissory note or a trade acceptance.

The Wholesale Census of 1939 reveals that 77.5 percent of the sales made by service and limited-function wholesalers were on a credit basis, and that 60 percent of all sales were extended for a period in excess of ro days. When the manufacturer sold directly to the retailer, 9I.7 percent of all sales were reported to be on credit, and 65 percent were for a credit period in excess of to days. ${ }^{4}$ This would appear to indicate that wholesalers and manufacturers carry on their books as receivables much of the inventory of retail stores; they are bankers in the sense of delivering goods for later payment in cash.

Since in excess of 60 percent of the retailers' purchases are for a credit period longer than the customary to days, the dependence of the retailer upon his supplier is evident. Historically, the substantial cash discount accorded the retail trade is linked to the heavy risk involved in extensions of credit, and even when credit risk has been reduced through closer contact with the retailer and through improved market information, the custom of giving this discount has continued, with the rate for retailers ranging from one to four per cent if the account is paid within a relatively short period. The two percent cash discount for payment within to days approaches standard practice and represents a substantial premium for prompt payment of the account. Assuming the annual sales volume of a small retailer to be $\$ 20,000$, the wholesale price of the goods he must purchase for his inventory in the course of a year would probably be in the neighborhood of $\$ 15,000$. A two percent discount on this figure would amount to $\$ 300$ a year, additional income which might well have the effect of taking the retailer out of the distinctively marginal group. Further, a retailer who has been able to discount his bills is likely to be placed on the preferred list compiled by distributors and manufacturers, and so may be given opportunities to participate in special offerings.

The question of why mercantile credit plays so important a role for the small retailer, as compared with bank credit, can be explained. In many instances, small retailers find it difficult or impossible to meet the requirements of commercial banks. Reasons for this are discussed elsewhere in this symposium. Manufacturers and wholesalers, however, by their use of bank credit do make such credit available indirectly to retailers who could not obtain it directly. Mercantile credit, be-

\footnotetext{
-U. S. Bur. of Census, Sixteenth Census of the United States (r94o) Census of Business, Vol. II, Wholesale Trade: I939, p. I12, Table 6A.
} 
sides being more easily obtained in many instances, is also generally tailored more closely to the needs of the different types of retail establishments, for credit extension and its maturity are at least roughly adjusted to the physical characteristics of the commodity and its marketability, to the merchant's inventory requirements and the particular trade's normally expected rate of inventory turnover, and when occasion warrants, to a sympathetic understanding of specific trade conditions.

Besides the conventional forms of mercantile credit, in which the manufacturer or distributor sells goods with a specific or implied date of payment, there are occasions when manufacturers place their products with retailers on consignment, and in so doing finance this portion of the retailers' inventories. Three reasons may be advanced to explain such a procedure. First, it enables the manufacturer to control distribution of his product and its retail price; electric light bulbs are an example in this instance. Second, the manufacturer of perishable products such as baked goods and frozen foods may wish to retain control of his product after it reaches the retailer, in order that he may supervise its freshness at the time of sale to the ultimate consumer, and by so doing insure consumer satisfaction and confidence in the manufacturer's brand. Third, a manufacturer may be desirous of effecting a quick and wide distribution of a new product and may feel that consignment selling will best accomplish his objective. Consignment merchandising represents only a small fraction of retail inventories, but its importance varies, of course, with the type of retail store. ${ }^{5}$

The heavy dependence of small retailers upon wholesalers and manufacturers for working capital raises the question of the extent to which this dependence is a handicap to the retailer. There is apprehension that the retailer, having accepted credit from a supplier, may be forced to his detriment to continue to do business with his creditor; in fact, it is asserted that it is not unusual for credit to be extended with the distinct understanding that subsequent purchases will be made from the creditor. This binds the retailer so that he may be forced to pay higher prices than are being quoted in the open market. Such higher prices may be called a hidden and excessive credit charge. Few will doubt that instances can be cited in which exploitation of retailers by wholesalers and manufacturers has taken place; but to assume that this is a general condition and, further, that it is one of the major handicaps of small retail business, seems at least questionable. Undoubtedly the marginal operator whom the trade recognizes as here today and gone tomorrow finds little consideration from suppliers, but, on the other hand, dealers who give evidence of managerial ability and character have been besieged by wholesalers and manufacturers who desire them to carry their lines. It is well known that in the thirties well established and financially strong distributors and manufacturers in

\footnotetext{
"Discussion of factoring, which from a legal point of view is close to consignment, is omitted from this presentation of small retailer credit sources. Factors operate almost exclusively in the wholesale market, being most prominent in the textile field. Except for some isolated cases, factoring in the United States had its origin in and does its business today in the financing of textile mills and garment manufacturers, serving as a form of specialized banking in these industries. Factoring has littlc pertinence to retailing.
} 
various lines felt obliged against their will to acquire certain retail outlets or to buy financial interest in retail establishments in order to be sure of satisfactory representation for their goods. Further, manufacturers have been known to pay sales bonuses to retailers with whom they have had successful relationships, to insure their financial soundness. Automobile, tire, paint and appliance manufacturers and oil processors were among those who gave such aid to affiliated retailers.

A mere comparison of the cost of credit to the small retailer and the cost to the large and well established corporation may naturally arouse sympathy for the small operator. But investigating and servicing credit extensions is costly, and until loans either become sizable or are periodically renewed and so become cumulatively substantial, the charges are inevitably high in proportion to the amount of credit extended. The cost of risk is high because there is exceptionally heavy mortality in small retailing. It is estimated that as many as $5^{\circ}$ percent of the failures are attributable to inadequate or poor management, ${ }^{6}$ and since the success of a small retail establishment depends so heavily upon the managerial skill of its owner, the extension of credit, unless well buttressed by collateral, must be treated very much like a personal loan. Cost of credit to small retailers is high not only because of losses to creditors through business failures, but also because such extensions frequently involve heavy collection expenses.

Under the stimulus of aggressive competition between suppliers, the active search for outlets for funds on the part of financial agencies, the increasing availability of market information, and the development of standard practices, the granting of mercantile credit is gradually becoming more scientific, and it appears reasonable to assume that reductions in credit cost will materialize.

\section{Financing of Accounts Recervable}

Working capital needs of merchants are primarily for inventory and the carrying of accounts receivable, and the relative importance of these depends upon the particular trade under discussion. It is probably safe to say that a majority of small retailers extend credit to their customers. This is substantiated to a considerable degree by the 1939 Retail Census, which estimates that 34 percent of the volume of retail sales is on credit. If sales by the large chain stores, particularly the variety and grocery chains which transact all business on a cash basis, were eliminated, in the neighborhood of 50 percent of the remaining volume of retail trade would be found to be done on credit.

Retail sales on credit can be divided into two segments, open account credit and installment credit. In the I939 Census, credit sales for which an analysis was reported indicated that 66.9 percent of this credit was open book, while 33.I percent was installment. From these figures it appears that in the most recent so-called "normal" period, two out of every three dollars of consumer credit arising out of

\footnotetext{
o Temporary National Economic Committee, Problems of Small Business, Monograph No. i7, Sen. Comm. Print, 76th Cong., 3d Sess. (I94I) I36.
} 
retail sales were open book credit and every third dollar was installment credit. In the discussion of mercantile credit, it was pointed out that such credit is frequently tailored to the needs of the retail merchant and that the period of settlement may be adjusted to the experiences retailers have in the collection of their open account extensions.

Except in unusual cases, the small retailer relies upon equity capital, bank credit or mercantile credit in the financing of his open book accounts. Conditions relative to open book or consumer charge accounts have gradually become standardized. In the period in which the majority of the population of this country was dependent upon agriculture for a living, the retailer was frequently obliged to carry his customers until after the harvest. With the improved cash position of farmers and agricultural workers and the shift from agriculture to industry and commerce where workers receive regular incomes on a weekly or monthly basis, merchants have been able to establish the custom that open account credit is due and payable within 30 days, or not later than 30 days from the first of the succeeding month. This practice has added a definiteness to date of payment which naturally instills greater confidence in such assets and increases their worth. The more rapid turnover of receivables has reduced the retailer's need for working capital.

Whereas the discounting of open account receivables with banks or financial institutions is not unusual in the case of manufacturers and wholesale distributors, it is very seldom employed by small retailers. In recent years, financial institutions and middlemen such as factors, discount houses, sales finance companies and, in some cases, commercial banks, have financed accounts receivable either by purchasing them or by accepting them as collateral, on a notification or non-notification basis. Financing of accounts has expedited the liquidation of such assets, assisting concerns in weak financial position, especially when such weakness indicated not that the business was failing but simply that sales were expanding faster than working capital. However, rates on this type of loan for small organizations in the highly competitive retail trade are so high as to be prohibitive, and their use generally indicates that a business is being liquidated.

Installment credit is generally associated with a contractual agreement requiring the amortization of a credit extension over a period of time, involving two or more " scheduled payments. While some "soft" goods are sold on this basis, durable consumer goods represent most of this form of credit. Furniture, jewelry, and some clothing retailers endeavor to finance such sales themselves, for various reasons, but probably primarily as a means of keeping contact with the customer and creating the necessity of his visiting the store periodically to pay on his account, at which times he may be induced to make further purchases. Such supplementary sales are generally referred to in the trade as "add-ons" and represent a substantial part of such stores' volume of business. Some other well-financed retailers in the household appliance and automobile businesses carry their own paper, but this practice is not the general rule, and in the automobile field probably less than ro percent of all time sales were financed by the dealer prior to 1942 . 
While the pledging of open account receivables is of minor importance among small retailers, the pledging of installment sales contracts for loans or the discounting of these contracts with the sales finance companies and other financial institutions is accepted as good practice and in some lines is regular procedure. For the purpose of illustrating its effectiveness in making working capital available for a retailer, a description of the process as it relates to the automobile dealer is given.

The sales finance companies which have carried the bulk of this business began in the early years of the present century and developed very rapidly after I9r4. The growth in size and number of this type of organization may be said to parallel the growth of the automobile industry. The very rapid expansion of sales of cars after World War I made financial demands upon dealers which they were unable to meet, especially since automobile manufacturers have from the beginning of the industry been able to require cash payment for new cars, either at the time they are ordered, prior to delivery, or immediately upon delivery, a practice which makes exceptionally heavy demands upon the dealer's working capital. Not being able to secure mercantile credit to finance his inventory, he found it essential to secure financial assistance in carrying his receivables. The resulting profitable character of such retail time sales paper naturally encouraged the starting of new companies and stimulated the growth of existing ones. Competition for profitable retail sales finance paper subsequently induced sales finance companies to offer to finance dealers' new and used car inventories at very reasonable rates, provided the dealer would agree to direct his retail sales paper to the accommodating firm. It has therefore been possible for an automobile dealer to have a substantial portion of his inventory financed and also be relieved of carrying his receivables. The automobile dealer's rather favored position can easily be explained, for in this line a high degree of product standardization has taken place, new and used market values have been stabilized and fluctuate only within relatively narrow limits, and a continuous, active, and nation-wide market has developed. Though the automobile appears in a favored position at present, similar conditions should develop in other lines as other consumer durable goods become standardized and develop stabilized values.

\section{Future Trends}

It hardly seems likely that one of the major problems of the postwar period will be the availability of credit for the small retailer. In meetings currently held for and by retailers, the problem of credit availability is seldom discussed. At present, retailers are probably in the best financial position they have ever occupied, and the same may be said of wholesale distributors and manufacturers. Banks, sales finance companies, factors, personal loan companies and other financial organizations are all confronted with the problem of finding safe and profitable outlets for their funds. There appears slight likelihood, therefore, of a shortage of credit. Since World War I, there have been significant developments in standardization and simplification of consumer products, especially in the field of convenience and 
durable goods and also in many shopping lines. This should result not only in lower inventory requirements and more rapid turnover, but also in the broadening of the market for such goods through encouraging the flow of these items from depressed to more favorable markets. This broader acceptability should not only help to maintain values on new goods but should definitely strengthen the market value of used merchandise, which should in turn increase market stability and so reduce credit costs. With the development of large-scale retailing, manufacturers of branded goods are more than ever cognizant of their dependence upon their retail outlets. Consequently, a coordinated effort on the part of manufacturer, distributor, and retailer to assist in the merchandising of dealer inventories should create greater confidence in the value of such inventories.

If the small retailer was once the forgotten man of the business world, he has now been discovered. Business research bureaus of universities and departments of the state and federal governments study his problem and offer suggestions; manufacturers of business machines prepare management aids; trade associations give managerial advice and supply consultants. All of these aids should take some of the hazards out of retailing, with the result that credit risk will be reduced and credit become easier and cheaper to secure. The availability of store rooms, the willingness of distributors of store equipment to sell or lease on low down payment and extended maturity, the ease with which inventories can be secured through generous extensions of mercantile credit, and the increasing ease of financing consumer receivables seem to give little support to the idea that it is difficult to embark upon a retailing career. In fact, there seems as much cause to question whether it has been too easy as whether it has been too hard. 